\title{
Thermodynamic Interpretation on the Rheology of Aqueous Bentonite Suspensions
}

\author{
İHSAN BOZDOĞAN ${ }^{1}$, MÜSERREF ÖNAL ${ }^{1, *}$, ABDULLAH DEVRIM PEKDEMIR ${ }^{2}$, \\ YÜKSEL SARIKAYA ${ }^{1}$ \\ ${ }^{1}$ Department of Chemistry, Faculty of Science, Ankara University, 06100 Ankara, Turkey \\ ${ }^{2}$ Institute of Mineral Research and Exploration, 06800 Ankara, Turkey
}

\begin{abstract}
Since their exceptional rheological behavior, bentonite suspensions are widely used in engineering, industrial, agricultural, and drilling applications. So, the aim of the present study is to investigate the rheological properties of three types aqueous suspensions prepared with calcium bentonite ( $\mathrm{CaB}$ ), sodium bentonite ( $\mathrm{NaB}$ ) obtained from that by $\mathrm{Na}_{2} \mathrm{CO}_{3}$ activation, and $\mathrm{NaB}$ with the excess soda. The $\mathrm{CaB}$ taken from Giresun/Turkey region contains calcium smectite $\left(\mathrm{C} a_{x} \mathrm{~S}\right)$ as clay mineral and opal $\mathrm{CT}\left(\mathrm{SiO}_{2} . \mathrm{nH}_{2} \mathrm{O}\right)$ as impurity which is paracrystalline silica. Soda content by the activation and bentonite content in the suspension were changed in the interval of 2.5-15.0\% and 5$20 \%$ by mass, respectively. $\mathrm{Ca} \mathrm{a}_{x} \mathrm{~S}$ completely converted to sodium smectite $\left(\mathrm{Na} \mathrm{a}_{2} \mathrm{~S}\right)$ by the activation with the soda content of $2.5 \%$ and then $\mathrm{Na}_{2 x} \mathrm{~S}+\mathrm{Na}_{2} \mathrm{CO}_{3}$ mixtures formed. Rheological properties of these aqueous suspensions were measured using a Fann Viscometer. These properties reached their maxima by the most thixotropic $\mathrm{Na}_{2 x} \mathrm{~S}$ suspensions and greatly increased with the increasing of smectite content. Rheological plots drawn of the shear rate vs. shear stress in the interval of 170-1020 $s^{-1}$ showed that the suspensions flow as a Bingham Plastic. Change in rheological properties depending on the smectite type and content as well as excess soda content was explained thermodynamically based on the chemical potential gradient between interlayer and dispenser waters.
\end{abstract}

Keywords: bentonite, rheology, suspension, yield stress

\section{Introduction}

Bentonitic clays are one of the most important industrial raw materials [1]. Their clay minerals are smectites such as montmorillonite, nontronite, saponite, beidellite and hectorite. Also, bentonites contain other clay and nonclay minerals as impurities [2,3]. Smectite minerals are hydrous hydroxylated aluminum, iron, and magnesium silicates. Their layered crystal structures are similar but the chemical compositions are different.

Smectites layers consist of one octahedral $(\mathrm{O})$ sheet between two tetrahedral $(\mathrm{T})$ sheets which are bonded by oxygen bridges [4]. This three sheets layer is pointed out as T-O-T or 2:1 abbreviation. Ideally, $\mathrm{Si}^{4+}$ and $\mathrm{Al}^{3+}$ can be found in the tetrahedral and octahedral sites, respectively. But, there is partial isomorphous substitution of $\mathrm{Si}^{4+}$ with the $\mathrm{Al}^{3+}$ in the tetrahedral sites as well as partial and/or complete ones of $\mathrm{Al}^{3+}$ with the $\mathrm{Fe}^{3+}, \mathrm{Fe}^{2+}, \mathrm{Mg}^{2+}$ or $\mathrm{Li}^{1+}$ in the octahedral sites. Thus, the 2:1 layers charged with the negative electric. This charge is balanced with the exchangeable cations such as $\mathrm{Na}^{+}$ and /or $\mathrm{Ca}^{2+}$ placed between 2:1 layers and their edges. The anhydrous thickness of the 2:1 layers is approximately $1.0 \mathrm{~nm}$. Pure smectite minerals are seldom found in the nature. Therefore, they have been isolated from bentonite by the purification process [5].

A mineral is called calcium smectite $\left(\mathrm{Ca}_{\mathrm{x}} \mathrm{S}\right)$ or sodium smectite $\left(\mathrm{Na}_{2 \times} \mathrm{S}\right)$, according to the exchangeable cation being $\mathrm{Ca}^{2+}$ or $\mathrm{Na}^{+}$. The air dried $\mathrm{Na}_{2 \times} \mathrm{S}$ and $\mathrm{Ca}_{x} \mathrm{~S}$ have one water sheet and two water sheets between the 2:1 layers, respectively. Therefore, the consecutive thickness of these hydrous 2:1 layers are $1.26 \mathrm{~nm}$ and $1.54 \mathrm{~nm}$. Similarly, clay which contains $\mathrm{Ca}_{\mathrm{x}} \mathrm{S}$ or $\mathrm{Na}_{2 \mathrm{x}} \mathrm{S}$ as major

\footnotetext{
*email: onal@science.ankara.edu.tr
} 
mineral is called calcium bentonite $(\mathrm{CaB})$ or sodium bentonite $(\mathrm{NaB})$. Beds of $\mathrm{CaB}$ are larger than those of $\mathrm{NaB}$ in the nature. On contrary, application areas of $\mathrm{NaB}$ are more than that of $\mathrm{CaB}$. Accordingly, $\mathrm{CaB}$ has been converted to $\mathrm{NaB}$ by treating with a sodium salt such as $\mathrm{Na}_{2} \mathrm{CO}_{3}$ [6-9].

The physical state of bentonites may be changed by increasing water content, from an anhydrous solid to a hydrated solid, plastic mud, gel and suspension, respectively [10,11]. Bentonite-water systems are of great importance for industrial, environmental and civil engineering activities [12-14].

Suspensions of $\mathrm{NaB}$ are generally used in oil engineering to make drilling and retaining fluids [1517]. Drilling fluids have been used to cool and lubricate the drill string and bit, ensure the stability and protection of the borehole walls, remove the catting from the bottom of the hole and bring them to the surface, and minimize the deposition of heavy rock fragments at the bottom of the hole when circulation is stopped $[18,19]$. To fulfill these different roles, the drilling fluid should have special rheological properties such as a high yield stress to prevent sedimentation [20-22].

The rheology of several aqueous suspensions was studied depending on the type and content of bentonite, electrolyte and additives as well as $p \mathrm{H}$-value and aging time [23-28]. Also, temperature affected greatly the rheological properties [29,30]. However, thermodynamic nature of aqueous bentonite suspensions has not yet been adequately discussed. Therefore, the aim of this study is the thermodynamic consideration on the rheological properties of the different aqueous bentonite suspensions.

\section{Materials and methods}

\subsection{Materials}

A calcium-rich bentonite $(\mathrm{CaB})$ having white color taken from the Tirebolu bed, Giresun/Turkey, was used in this study as raw material. The bulk chemical analysis of the $\mathrm{CaB}$ (mass \%) is; $\mathrm{SiO}_{2} \mathbf{7 2 . 1 0}$; $\mathrm{Al}_{2} \mathrm{O}_{3}, 14.69 ; \mathrm{Fe}_{2} \mathrm{O}_{3}, 0.94 ; \mathrm{TiO}_{2} 0.20 ; \mathrm{MgO}, 2.55 ; \mathrm{CaO}, 0.36 ; \mathrm{Na}_{2} \mathrm{O}, 0.35 ; \mathrm{K}_{2} \mathrm{O}, 0.42$ and loss on ignition (LOI), 8.40. The $\mathrm{CaB}$ was ground to pass through $74 \mu \mathrm{m}$ (200 mesh) sieve and heated at 105 ${ }^{\circ} \mathrm{C}$ for $24 \mathrm{~h}$. The dried $\mathrm{CaB}$ powder was stored in a plastic bottle for using later experiments. Analytically pure anhydrous sodium carbonate $\left(\mathrm{Na}_{2} \mathrm{CO}_{3}\right)$ used by soda activation was obtained from Merck Chemical Company.

\subsection{Soda activation}

Five powders, each having a mass of $20 \mathrm{~g}$, were weighed from the stock $\mathrm{CaB}$. The powders were mixed with $\mathrm{Na}_{2} \mathrm{CO}_{3}$ powder. The mass percentage of pure $\mathrm{Na}_{2} \mathrm{CO}_{3}$ in the solid mixtures was in order to $0,2.5,5,10$, and 15 . The corresponding soda activated bentonite samples were denoted to be S0, S2.5, S5, S10, and S15. Each powder mixture was homogenized using a Pascal Instrument for 20 min. Distilled water was added to the powder mixtures until to form a gel. After extrusion using a Netzsch Instrument each gel was kept in tightly closed plastic bottle for $24 \mathrm{~h}$, activated samples were dried at $105{ }^{\circ} \mathrm{C}$ for $4 \mathrm{~h}$ and then ground to pass through a $74 \mu \mathrm{m}$ (200 mesh) sieve using a Siebe-Technic Instrument and stored in the tightly closed plastic bottles to use by rheological measurements.

\subsection{XRD- analysis}

The X-ray diffraction (XRD) patterns of natural and soda activated samples were performed from random mounts prepared by glass slide method with a Rikagu D-Max 2200 Powder Diffractometer, operating of $40 \mathrm{kV}$ and $30 \mathrm{~mA}$, using $\mathrm{Ni}$ filtered $\mathrm{CuK}_{\alpha}$ radiation having $0.15418 \mathrm{~nm}$ wavelength.

\subsection{Rheological measurements}

Different aqueous suspensions were prepared using the natural and soda activated samples. The mass percent for each activated sample in the suspension was in order to 5, 10, 15 and 20 by mass. The corresponding suspensions were respectively denoted to be B5, B10, B15 and B20. So, overall twenty different aqueous suspensions were obtained. Each suspension was stirred using a Fischer Propeller Stirrer for $5 \mathrm{~min}$ and then left at rest. The rest time was increased up to 9 days at $25^{\circ} \mathrm{C}$. Viscosity of the 
suspensions was measured using a Fann Viscometers in everyday [31-32]. The optimum rest time in which the viscosity reached a maximum was estimated to be 5 days, and further rheological measurement were realized after this rest time. Shear stress for each suspension was measured at equilibrium established in the optimum rest time with respect to the shear rate ranged from 170 to $1020 \mathrm{~s}^{-1}(100-600 \mathrm{rpm})$ using a Fann Viscometer.

\section{Results and discussions}

\subsection{Mineralogy}

The XRD-patterns (F1gure 1) indicated that the natural bentonite contains a Ca-rich smectite $\left(\mathrm{Ca}_{\mathrm{x}} \mathrm{S}\right)$ with a value of $d_{001}=1.524 \mathrm{~nm}$ as major clay mineral and opal-CT with a value of $d_{101}=0.401 \mathrm{~nm}$ which is a paracrystalline silica polymorph $\left(\mathrm{SiO}_{2} \cdot \mathrm{nH}_{2} \mathrm{O}\right)$. The decrease in $\mathrm{d}_{001}$ from 1.524 to $1.195 \mathrm{~nm}$ showed that the $\mathrm{Ca}_{\mathrm{x}} \mathrm{S}$ converted approximately to $\mathrm{Na}_{2 \mathrm{x}} \mathrm{S}$ by all soda activations. Since the intensity and position remained constant, this means that the opal-CT did not affected from the soda activation. The effect of opal-CT on the rheological properties of the bentonite suspensions was assumed as insignificant compared to the smectites. Accordingly, $\mathrm{Ca}_{x} \mathrm{~S}$ and $\mathrm{Na}_{2 \times} \mathrm{S}$ symbols will be used instead of those $\mathrm{CaB}$ and $\mathrm{NaB}$ in following discussions.

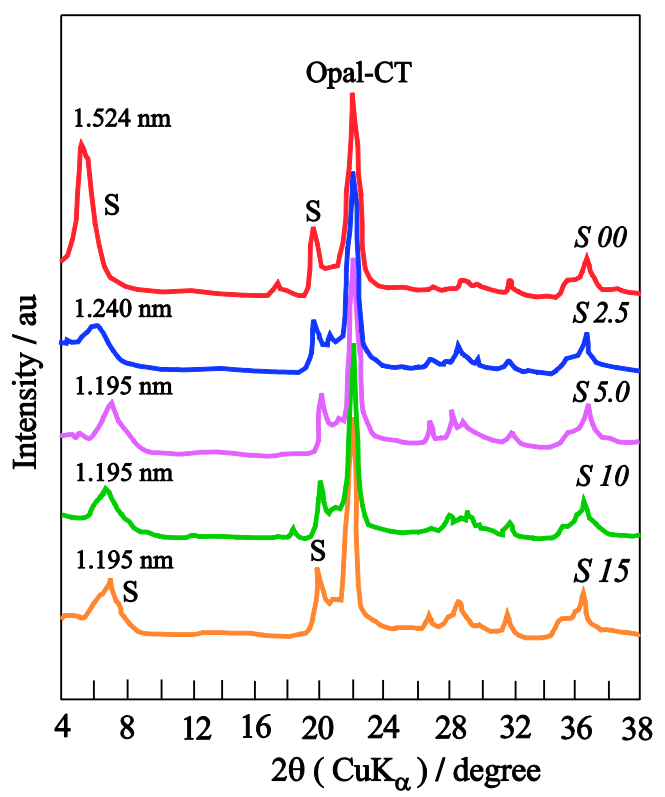

Figure 1. XRD patterns of the natural and soda activated bentonite samples

\subsection{Viscosity}

Viscosity is a measure of the resistance to flow of the fluids as well as to move of the solids within. The viscosity of a fluid after yielding is called appearance or plastic viscosity. Change in the appearance viscosity $(\eta)$ of the B15 suspension for the soda activated sample (S2.5, S5, S10, and S15) with respect to rest time was represented in Figure 2. Appearance viscosity of the suspension for the S2.5 and S5 samples increased with the rest time during the first five days and then progressively decreased to their constant value, whereas for the S10 and S15 samples remained constant. Since their appearance viscosity changed with the rest time, aqueous suspensions of the S2.5 and S5 samples are thixotropic. Excess soda in the S10 and S15 samples would be hindered the thixotropy in their aqueous suspensions.

Change in appearance viscosity of the suspensions (B5, B10, B15, and B20) with respect to the soda content used by activation was given in Figure 3. Appearance viscosity of the suspensions increased greatly with increasing of $\mathrm{Na}_{2} \mathrm{CO}_{3} \%$, reaching a maximum at about $2.5 \%$, and then 
progressively decreased to near initial value. Appearance viscosity of the suspension prepared with the bentonite content of $20 \%$ by mass was found to be higher than those others. Consequently, appearance viscosity of the aqueous suspensions increased greatly by increasing of $\mathrm{Na}_{2 \times} \mathrm{S}$ content whereas this does not happen for $\mathrm{Ca}_{x} \mathrm{~S}$ and $\mathrm{Na}_{2} \mathrm{CO}_{3}$.

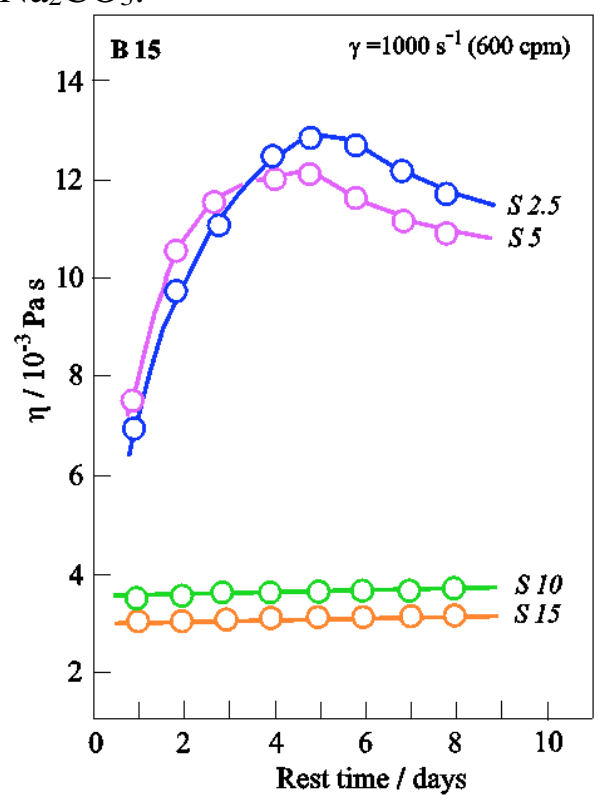

Figure 2. Change in appearance viscosity of the B15 suspension for the soda activated sample (S2.5, S5.0, S10, and S15) with respect to rest time $\left(10^{-3} \mathrm{~Pa} \mathrm{~s}=1 \mathrm{cP}\right)$

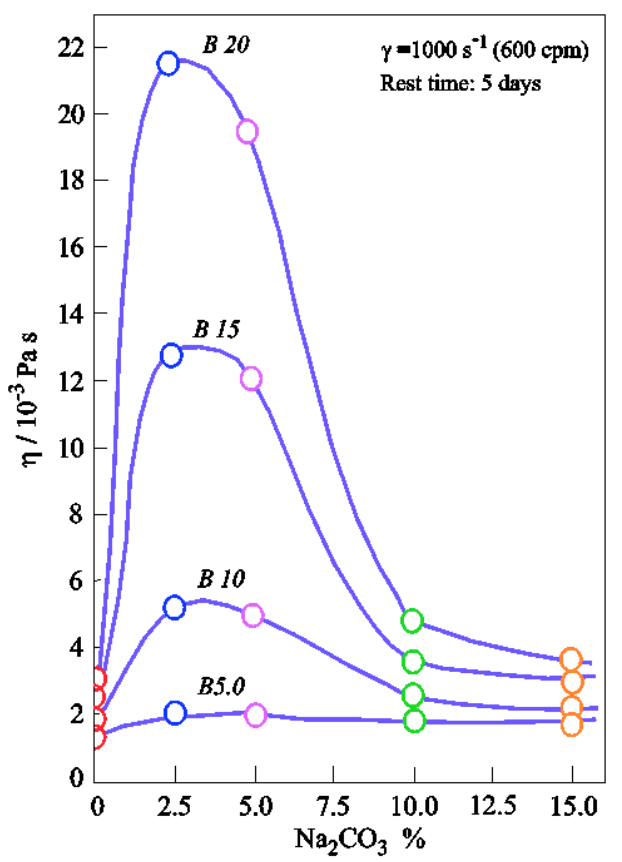

Figure 3. Change in appearance viscosity of the suspensions (B5, B10, B15, and B20) with respect to the soda content used by activation $\left(10^{-3} \mathrm{~Pa} \mathrm{~s}=1 \mathrm{cP}\right)$ 


\subsection{Rheological plots}

Rheological behavior of suspensions is examined in terms of the relationship between the shear stress and shear rate. Shear stress $(\tau)$ is defined as the tangential force applied per unit area and shear rate $(\gamma=d v / d x)$ as the change of strain per unit time. The rheological plot of the shear stress $v s$. shear rate also called flow or consistency graph.

Rheological plots of the B20 suspensions prepared with the S00, S2.5, S5.0, S10 and S15 powders were given in Figure 4. The shear stress of the suspensions increased linearly with the increasing of the shear rate in the interval of 170-1020 s-1. The obtained straight lines revealed that the flow of the suspensions is Bingham plastic type and fits the equation given as follows [33-37];

$$
\tau=\tau_{0}+k \gamma
$$

where $\tau_{0}$ and $k$, are yield stress and consistency index, respectively. Yield stress is the amount of the shear stress required to initiate flow. The $\mathrm{k}$ parameter indicates the degree of non-Newtonian characteristic for suspensions.

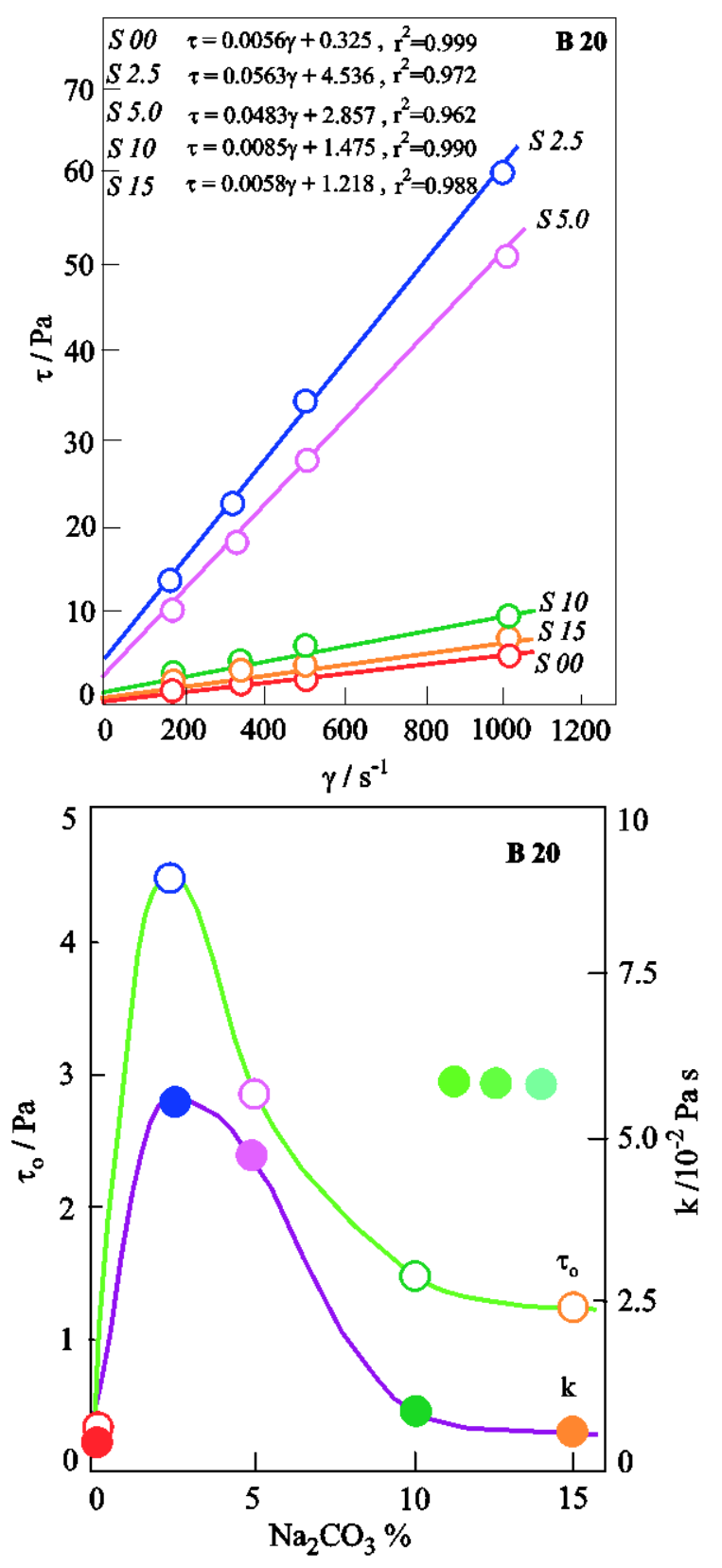

Figure 4. Rheological plot of B20 suspensions of the soda activated bentonite samples (S00, S2.5, S5.0, S10, and $\mathrm{S} 15)$ 
The $\tau_{0}$ and $k$ values for the B20 suspensions were evaluated from the intercept and slope of the rheological straight lines, respectively. The variation of these parameters with respect to the soda content by the activation was given in Figure 5. Thus, the yield stress and consistency have parallel change to each other with the soda content. This indicated that the van der Waals forces between particles and accordingly yield stress change depending on the consistency of the bentonite suspensions.

\subsection{Thermodynamic considerations}

Rheological properties of aqueous suspensions of smectites would be explained with the chemical potential gradients of water. Chemical potential is defined as the molar Gibbs energy of a component. Chemical potential of water $\left(\mu_{1}\right)$ in a solution changes depending on the temperature $(T)$, pressure $(p)$, and mole fraction $\left(x_{1}\right)$ given as below

$$
\mu_{1}\left(T, p, x_{1}\right)=\mu_{1}^{*}(T, p)+R T \ln x_{1}
$$

where $\mu_{1}^{*}(T, p)$ is the chemical potential of bulk water at constant $T$ and $p$, and $R$ is the universal gas constant. This chemical potential increases with the increasing of mole fraction and applied pressure at constant temperature. Pressure derivative of the chemical potential for water in the solution is given as below

$$
\left(\partial \mu_{1} / \partial p\right)_{T}=\bar{V}_{1}
$$

where $\bar{V}_{1}$ is the partial molar volume of water. Chemical potential of water in the suspension changes depending on the content of dissolved components such as $\mathrm{Na}_{2} \mathrm{CO}_{3}$ but not the suspended particles. The gradient of chemical potential is the driving force of mass transfer. So, change in the rheological properties of the aqueous smectite suspensions is due to the spontaneous flow of water through from high to low chemical potential sites. Electrostatic attractive forces arise between the exchangeable cations and negatively charged T-O-T layers are caused face to face (F-F), edge-to-face (E-F) and edge to edge (E-E) orientations between these particles. Since the negative charge is more concentrated on the face rather than edge of the T-O-T layers, the formation probability of the orientations would be decreased in order to F-F, E-F, and E-E. Rheological properties of the aqueous smectite suspensions should be changed depending on the bulk water content which diffused spontaneously between T-O-T layers of these orientations.

\subsection{Suspensions of $\mathrm{CaxS}$ in bulk water}

Chemical potential of bulk water is maximum whereas it is zero in dried $\mathrm{Ca}_{\mathrm{x}} \mathrm{S}$. So, water molecules penetrated spontaneously between the oriented T-O-T layers in dried $\mathrm{Ca}_{\mathrm{x}} \mathrm{S}$. Crystalline swelling is due to the hydration of $\mathrm{Ca}^{2+}$ cations. The relatively strong electrostatic attractive forces between the divalent calcium cations and T-O-T layers applied a pressure on the interlayer water. So, chemical potential of the interlayer water increased rapidly by increasing of the pressure until it reached to chemical potential of the bulk water. This equality indicated that the thermodynamic equilibrium was established and hindered flow of more water to interlayers. So, the rheological properties do not greatly change with the bentonite content in the aqueous suspensions (Figure 3).

\subsection{Suspensions of $\mathrm{Na} 2 \mathrm{~S}$ in bulk water}

Calcium smectite converted to sodium smectite by the activation with the soda content of $2.5 \%$ by mass (Figure 1). Cation exchange reaction by this conversion can be written as below

$$
\mathrm{Ca}_{x} \mathrm{~S}+\mathrm{xNa}_{2} \mathrm{CO}_{3} \rightarrow \mathrm{Na}_{2} \mathrm{~S}+\mathrm{xCaCO}_{3}
$$

The crystals of $\mathrm{CaCO}_{3}$ remain undissolved and unsuspended in bulk water. 
The relatively weak electrostatic attractive forces between the monovalent $\mathrm{Na}^{+}$cations and $\mathrm{T}-\mathrm{O}-\mathrm{T}$ layers applied lower pressure on the interlayer water than those divalent $\mathrm{Ca}^{2+}$ cations. In other words, chemical potential difference between the bulk and interlayer waters in the $\mathrm{Na}_{2 \times} \mathrm{S}$ suspensions is higher than these of $\mathrm{Ca}_{\mathrm{x}} \mathrm{S}$ ones. So, more water molecules penetrated spontaneously between the T-O-T layers of dried $\mathrm{Na}_{2 x} \mathrm{~S}$ until to established a thermodynamic equilibrium. Crystalline and osmotic swellings occurred by the penetration of extra water between the T-O-T layers of the $\mathrm{Na}_{2 x} \mathrm{~S}$ [38,39]. Crystalline and osmotic swellings have been discussed based on the hydration of $\mathrm{Na}^{+}$cations and formation of Gouy-Chapman diffuse electric double layer theory, respectively. Diffuse electric double layers around the T-O-T layers slow down their motion and cause an increase in the rheological properties such as viscosity, shear stress and yield stress of the aqueous $\mathrm{Na}_{2 x} \mathrm{~S}$ suspensions (Figures 3-5).

\subsection{Suspensions of $\mathrm{Na}_{2} \mathrm{~S}$ in $\mathrm{Na}_{2} \mathrm{CO}_{3}$ solution}

During cation exchange reaction (4) between $\mathrm{Ca}_{\mathrm{x}} \mathrm{S}$ and excess soda larger than $2.5 \%$ by mass, the excess $\mathrm{Na}_{2} \mathrm{CO}_{3}$ still dissolved in water while the formed $\mathrm{CaCO}_{3}$ remains undissolved. Each heterogeneous mixture of the reaction product and water is a suspension of $\mathrm{Na}_{2 \times} \mathrm{S}$ in the aqueous $\mathrm{Na}_{2} \mathrm{CO}_{3}$ solution.

Chemical potential of water in the soda solution is lower than that of bulk water and decreases progressively by increasing of the soda content. However, chemical potential of water in the diffuse electric double layers found in thermodynamic equilibrium is equal to that of bulk water. So, water with the higher chemical potential flows spontaneously from the diffuse electric double layers to the soda solution. The decrease of water content causes to destroy of the diffuse electric double layers. Values of the rheological properties such as viscosity, shear rate and yield stress of the suspension are rapidly reducing by the effect of the progressive disappearing of the diffuse electric double layer found at the around of each oriented T-O-T layer.

\section{Conclusions}

Calcium smectite can be converted to sodium smectite by an ion exchange reaction such as soda activation. Different blends of calcium smectite and sodium smectite can be obtained depending on the soda content by the activation to gain the optimum rheological properties for each uses. Changes in the rheological behavior of smectite suspensions can be thermodynamically explained by the water flow based on the chemical potential gradient between the interlayer water and water as bulk or component in solution.

Acknowledgments: This work received financial support from The Scientific and Technological Research Council of Turkey (TBAG-949) and Ankara University Research Fund (16L0430013).

\section{References}

1.GRIM, R.E., Clay Mineralogy, McGraw- Hill, New York, 1968.

2.MURRAY, H.H., Appl. Clay Sci. 17, 2000, p. 207.

3.BERGAYA, F., THENG, B.K.G., LAGALY, G., Handbook of Clay Science, (Developments in Clay Science), Volume 1, Elsevier, Amsterdam, 2006.

4.MOORE, D.M., REYNOLDS JR. R.C., X-Ray Diffraction and the Identification and Analysis of Clay Minerals, Oxford University Press, New York, 1997.

5.ÖZGÜVEN, E., PEKDEMIR, A.D., ÖNAL, M., SARIKAYA. Y., J Turkish Chem. Soc. 7, 202, p. 11.

6.BLEIFUSS, R.L., Clay Miner. 10, 1973, p. 41.

7.LAGALY, G., VONMOSS, M.M., FAHR, G., RAHR, R., Keram. Zeitschrift 33, 1981, p. 278.

8.MAGZOUB, M.I., NASSER, M.S., HUSSEIN, I.A., BENAMOR, A., ONAIZI, S.A., SULTAN, A.S., MAHMOUD, M.A., Appl. Clay Sci. 147, 2017, p. 176. 
9.SCHEID, C.M., de CARVALHO, R.V., de OLIVEIRA, B.R., de OLIVEIRA, R.F., CALÇADA, L.A., J. Petrol. 174, 2019, p. 563.

10.LOW, P.F., Soil Sci. Soc. Am. J. 43, 1979, p. 651.

11.LUCKHAM, P.F., ROSSI, S., Adv. Interf. Sci. 82, 1999, p. 43.

12.ROLLINS, M.B., Clays Clay Miner. 16, 1969, p. 415.

13.YONG, R.N., Eng. Geol. 54, 1999, p. 3.

14.WERSIN, P., CURTI, C., APPELO, A.J., Appl. Clay Sci. 26, 2004, p. 249.

15.JOZEFACIUK, G., BOVANKO, G., Clays Clay Miner. 50, 2002, p. 771.

16.AL-ZUBAIDI, N.S., ALWASITI, A.A., MAHMOUD, D., Egypt. J. Petrol. 26, 2017, p. 811.

17.AFOLABI, R.O., ORODU, O.D., EFEOVBOKHAN, V.E., Appl. Clay Sci. 143, 2017, p. 39.

18.ABDOU, M.I., ABUSEDA, H., Egyptian J. Petrol. 23, 2014, p. 213.

19.AGWU, O.E., AKPABIO, J.U., ALABI, S.B., DOSUNMU, A., Powder Technol. 339, 2018, p. 728.

20.BENNA, M., KBIR-ARIGUIB, N., MAGNIN, A., BERGAYA, F., J. Colloid Interf. Sci. 218, 1999, p. 442.

21.BARAN, B., ERTÜRK, T., SARIKAYA, Y., ALEMDAROĞLU, T., Appl. Clay Sci. 20, 2001, p. 53.

22.ZHAO, X., QİO, Z., HUANG, W., WANG, M., J. Petrol. Sci. Eng. 154, 2017, p. 405.

23.MANEA, M., Rev. Chim. 63, 2012, 1132.

24.KUMAR, R., KUMAR, V., RAJAK, D.K., GURIA, C., Inter. J. Miner. Process. 126, 2014, p. 18.

25.SISODIA, M.S., RAJAK, D.K., PATHAK, A.K., GURIAJ. C., J. Petrol. Sci. Eng, 125, 2015, p. 247.

26.VRYZAS, Z., NALBANDIAN, L., ZASPALIS, V.T., KELESSIDIS, V.C., J. Petrol. Sci. Eng. 173, 2019, p. 941-954.

27.MERAD, B., BEKKOUR, K., GARECHE, M., Appl. Clay Sci. 184, 2020, 105321, p. 1.

28.AKKOUCHE, A., BENMOUNAH, A., GUECIOUER, A., CHALAH, K., Egyptian J. Petrol. DOI: 10.1016/j.ejpe.2019.12.005 (in press).

29.LIN, Y., CHEAH, L.K-J., THIEN, N.P., KHOO, B.C., Colloids Surf. A Physicochem. Eng. Asp. 506, 2016, p. 1.

30.AFOLOBI, R.O., YUSUF, E.O., Powder Tech. DOI: 10.1016/j.apt.2019.10.023 (in press).

31.CRUZ, N., PENG, Y., Miner. Eng. 98, 2016, p. 137.

32.ANDAVERDE, J.A., WONG-LOYA, J.A., VARGAS-TABARES, Y., ROBLES, M., J Petrol. Sci. Eng. 180, 2019, 150.

33.NORRISH, K., Faraday Discuss. 57, 1954, p. 110.

34.LARIBI, S., FLEUREAU, J-M., GROSSIORD, J-L., KBIR-ARIGUIB, N., Rheol. Acta 44, 2005, p. 262.

35.CHOO, K.Y., BAI, K., Appl. Clay Sci., 108, 2015, p. 182.

36.CVEK, M., MRLIK, M., PAVLINEK, V., J. Rheol. 60, 2016, p. 687.

37.MA, T., YANG, R., ZHENG, Z., SONG, Y., J. Rheol. 61, 2017, p. 205.

38.CHRISTIDIS, G.E., BLUM, A.E., EBERL, D.D., Appl. Clay Sci. 34, 2006, p. 125.

39.ÖNAL, M., Appl. Clay Sci. 37, 2007, p. 74.

Manuscript received: 27.02 .2020 